\title{
Effects of magnesium ions in microbial cells adhesion of attached growth system for the enhancement of biogas production
}

\author{
Nabilah Aminah Lutpi ${ }^{*}$, Wong Yee Shian, Tengku Nuraiti Tengku Izhar, Yiek Wee Kiong \\ School of Environmental Engineering, Universiti Malaysia Perlis, 02600, Arau, Perlis, Malaysia \\ * Corresponding author: nabilah@unimap.edu.my
}

\section{Article history}

Received 12 January 2019

Revised 5 May 2019

Accepted 10 October 2019

Published Online 2 February 2020

Graphical abstract

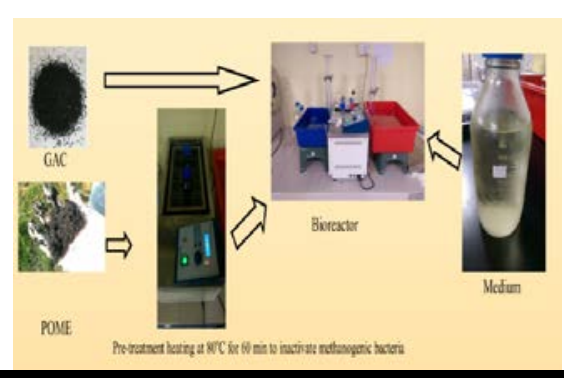

\section{Abstract}

This research aims to improve the biogas production by employing cell immobilisation technique under thermophilic conditions. The thermophilic fermentative biogas production was carried out by immobilising the anaerobic sludge obtained from palm oil mill treatment plant on granular activated carbon (GAC) in repeated batch mode. Different concentration of magnesium ions $\left(\mathrm{Mg}^{2+}\right)(0.25,0.5,0.75,1.0$ and $1.5 \mathrm{~g} / \mathrm{l})$ on biogas production was investigated at $60^{\circ} \mathrm{C}$ with an initial sucrose concentration of $5 \mathrm{~g} / \mathrm{l}$ as feedstock. The effect of $\mathrm{Mg}^{2+}$ supplementation at the initial stage of immobilisation process is important to increase the formation of biofilm in the attached growth system. This study had found that $\mathrm{Mg}^{2+}$ could enhance the biogas production capacity with optimum $\mathrm{Mg}^{2+}$ concentration of $0.75 \mathrm{~g} / \mathrm{l}$.

Keywords: Biogas, biofilm, thermophilic, magnesium, immobilisation

C 2020 Penerbit UTM Press. All rights reserved

\section{INTRODUCTION}

Biogas production via anaerobic dark fermentation has generated a lot of interest among the researchers and has led to a proliferation of studies, which heightened the need to improve the biogas production system performance. The issue of low-yield of biogas is the main bottleneck in current biogas production technologies, which need to be addressed. One of the available solution to improve the biogas yield is by direction of metabolic fluxes that can be accomplished through thermophilic fermentation.

On the other hand, lower cell density was the main challenge faced by several reported studies operated under thermophilic conditions, since most of them were focused on the suspended cell cultures [1]. Therefore, biogas production by thermophilic dark fermentation requires further improvement on cell density, in order to achieve the goal for a superior biogas performance. As an alternative, strategies have been proposed in keeping the culture density and at the same time increasing biogas performance by employing attached growth system under thermophilic condition. There are several approaches to enhance the biogas production through attached growth studies, including optimization of cation ions that could exert their influence during immobilisation process.

Cation such as magnesium ion $\left(\mathrm{Mg}^{2+}\right)$ is essential for the growth and cell division of cells. However, the need of this cation for growth is depending on the reaction of the organism itself [2]. Simple chemically define media is a good option to explain whether the specific bacteria involve in the process could stimulates the growth with the addition of the cation such as $\mathrm{Mg}^{2+}$. Therefore, this study was employed to determine the effect of $\mathrm{Mg}^{2+}$ in microbial cells adhesion of attached growth system for the enhancement of biogas production using define media with sucrose as the sole carbon source.

\section{EXPERIMENTAL}

The anaerobic sludge obtained from United Oil Palm Industries Sdn Bhd in Nibong Tebal, Penang was used as the seed sludge in this study. The efficiency of the seed sludge was enhanced by heating at $80^{\circ} \mathrm{C}$ for 1 hour to inhibit the methanogenic activity [3]. The thermally treated sludge was further used for batch fermentation study using $500 \mathrm{ml}$ Duran bottle with $250 \mathrm{ml}$ of total working volume. The total working volume for each bottle consists of $25 \mathrm{ml}$ sludge that were enriched with $225 \mathrm{ml}$ of synthetic medium, containing sucrose (5

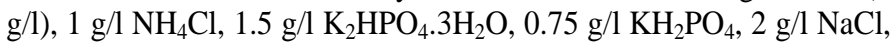
$0.05 \mathrm{~g} / \mathrm{l} \mathrm{CaCl} .2 \mathrm{H}_{2} \mathrm{O}, 0.5 \mathrm{~g} / \mathrm{l}$ cystein $\mathrm{HCl}, 2 \mathrm{~g} / \mathrm{l}$ yeast extract, $2.6 \mathrm{~g} / \mathrm{l}$ $\mathrm{NaHCO}_{3}$, and $1 \mathrm{ml} / \mathrm{l}$ trace element [4]. The granular activated carbon (GAC) of $25 \mathrm{~g}$ was also added to the mixture which functions as host and attached media for cell growth. Study on the effect of $\mathrm{Mg}^{2+}$ supplementation was conducted by adding different concentration of magnesium chloride in the ranges of $0.25 \mathrm{~g} / \mathrm{l}$ to $1.5 \mathrm{~g} / \mathrm{l}$ in the mixture. Sample without any supplementation of $\mathrm{Mg}^{2+}$ was also prepared for fermentation and was assigned as a control sample (blank). The $\mathrm{pH}$ of mixture was adjusted to 5.5 using $1 \mathrm{M} \mathrm{NaOH}$ or $1 \mathrm{M} \mathrm{HCl}$. Prior to incubation, the bottle was purged with nitrogen to provide an anaerobic condition for dark fermentation process. The samples were incubated at $60^{\circ} \mathrm{C}$ with $150 \mathrm{rpm}$ of agitation. The batch cultivation was repeated for ten cycles, whereby each of the cycle was conducted for 24 hours to ensure the biofilm formed on the GAC generated a stable biogas production. The biogas composition was measured using 
gas analyzer (Model GA5000) and the liquid samples were analysed for total carbohydrate using phenol sulphuric acid method to obtain the sugar consumption during fermentation [5].

\section{RESULTS AND DISCUSSION}

\section{Biogas production}

Figure 1 shows the volume of biogas produced for different concentration of $\mathrm{Mg}^{2+}$. Based on the observation, the performance of biogas production was enhanced in the presence of $\mathrm{Mg}^{2+}$. The control samples without the addition of $\mathrm{Mg}^{2+}$ presented the lowest volume of biogas compared to others. The data had proven that $\mathrm{Mg}^{2+}$ could influence the biofilm development, similar to the claim by Pasternak et al. [2] which have reported that $\mathrm{Mg}^{2+}$ capable to increase the abundance of attached cells, by reducing the repulsive force between the negatively charged bacterial and substratum surface. Meanwhile, Feng et al. [6] in their study had found that $0.3 \mathrm{~g} / \mathrm{l} \mathrm{of} \mathrm{Mg}^{2+}$ have significantly enhanced the biogas production performance to $256 \mathrm{ml}$ $\mathrm{H}_{2} / \mathrm{l}$ using hydrogen-producing zymogenous bacteria YUAN-3 (Ethanoligenens harbinense). In the case of this study, the adhesion of microbes onto GAC due to the presence $\mathrm{Mg}^{2+}$ and the correlation with the increment of biogas performance, indicated that $\mathrm{Mg}^{2+}$ plays the role to facilitate cell adhesion in the immobilisation process and improved the biogas production. The results showed that $\mathrm{Mg}^{2+}$ with concentration in the range of 0.75 to $1.5 \mathrm{~g} / \mathrm{l}$ have depicted high but almost similar biogas production. Hence, in terms of economical aspect for medium preparation, $\mathrm{Mg}^{2+}$ with concentration of $0.75 \mathrm{~g} / \mathrm{l}$ was chosen as the optimal value for enhancement of biogas production. In addition, the performance of sugar consumption by microbial cells was the highest with the supplementation of $\mathrm{Mg}^{2+}$ at the concentration of $0.75 \mathrm{~g} / \mathrm{l}$.

Furthermore, a lighted wooden splinter has been used to confirm the presence of hydrogen gas in the biogas collected. When the lighted wooden splinter was contacted with the gas collected, a pop sound was heard, hence proved the existence of the hydrogen gas in the biogas collected.

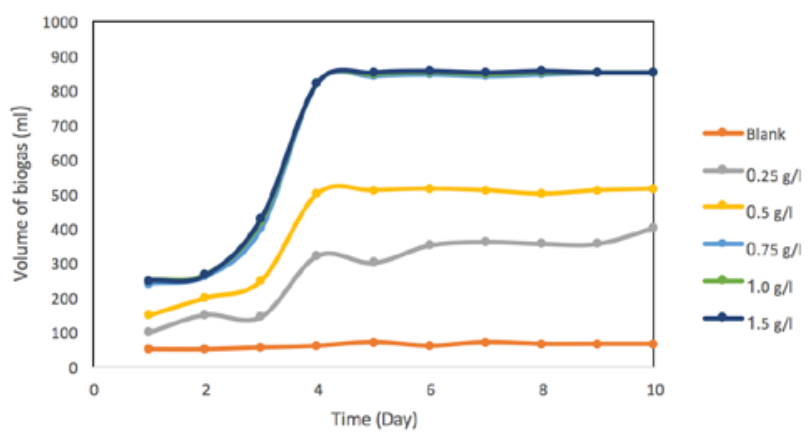

Figure 1 Production of biogas with different range of $\mathrm{Mg}^{2+}$ concentration.

\section{Total carbohydrate analysis}

Figure 2 shows the percentage of sugar consumption by the microorganisms in different concentration of $\mathrm{Mg}^{2+}$. The control batch fermentation illustrates the lowest percentage of sugar consumption which is $38.25 \%$. The supplementation of $\mathrm{Mg}^{2+}$ is crucial as it is essential for the normal cell division of microorganisms [7]. Therefore, the low sugar consumption detected in this study was presumably due to failure of microorganisms to grow in the complete absence of $\mathrm{Mg}^{2+}$. In addition, less biofilm development during the fermentation will cause the population level of microorganisms to decrease, thus causing the low sugar consumption to convert the energy into the biogas production. Moreira et al. [8] has mentioned that higher amount of biofilm will be developed when the consumption of sugar level increased.

Besides that, the sugar consumption by microorganisms could also be influenced by increasing the concentration of cation. For instance, the percentage of sugar consumed by the microorganisms will be increased at higher $\mathrm{Mg}^{2+}$. Figure 2 illustrates the percentage of sugar consumption is higher for the supplementation of $0.50 \mathrm{~g} / \mathrm{M} \mathrm{Mg}^{2+}$ compared to $0.25 \mathrm{~g} / \mathrm{l} \mathrm{Mg}^{2+}$. According to Zhang et al. [9], the system with higher level of $\mathrm{Mg}^{2+}$ offers an advantage to the growth of sulphate reducing bacteria.

The optimum percentage of sugar consumption by microorganisms remain constant at range of $88 \%-89 \%$ for concentration of $\mathrm{Mg}^{2+}$ at $0.75 \mathrm{~g} / \mathrm{l}, 1.00 \mathrm{~g} / \mathrm{l}$ and $1.50 \mathrm{~g} / \mathrm{l}$. $\mathrm{Ng}$ et al. [10] reported that the growth rate of the species (amount of microorganisms attached as biofilm) were positively correlated to the amount of glucose (amount of sugar consumption). This is because, the addition of $\mathrm{Mg}^{2+}$ will reduce the electrostatic repulsion between the negatively charged bacteria and increase the formation of biofilm in the attached growth system. Biofilm formation is one of the most successful strategies for survival in a natural environment, which protect and facilitate the growth of bacteria under unfavourable conditions, such as turbulent flow or limited access to nutrients [11][12].

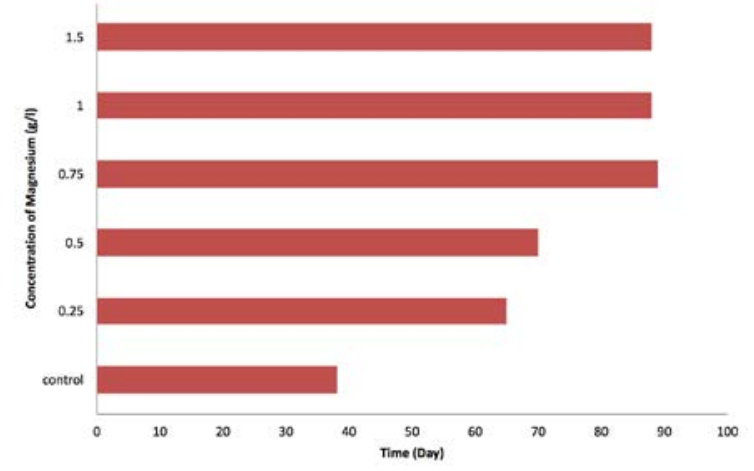

Figure 2 Concentration of magnesium versus the percentage of sugar consumption based on total carbohydrate analysis.

\section{CONCLUSION}

In this research, the effect of $\mathrm{Mg}^{2+}$ at different concentrations has been studied in attached growth system for the enhancement of biogas production. Supplementation of $\mathrm{Mg}^{2+}$ has aid in reducing the electrostatic repulsion between negatively charged bacteria into the seed sludge for a good adhesion towards the granular activated carbon, and also biogas performance. The optimum range of $\mathrm{Mg}^{2+}$ obtained in this study was $0.75 \mathrm{~g} / \mathrm{l}$ by considering the performance of biogas produced and sugar consumption by the immobilised cells.

\section{ACKNOWLEDGEMENT}

This research is fully supported by FRGS grant (FRGS No: 900300511). The authors fully acknowledged Ministry of Higher Education (MOHE) and Universiti Malaysia Perlis (UniMAP) for the approved fund which makes this important research viable and effective.

\section{REFERENCES}

[1] O-Thong, S., Prasertsan, P., Karakashev, D., Angelidaki, I. 2008. Highrate continuous hydrogen production by Thermoanaerobacterium thermosaccharolyticum PSU-2 immobilized on heat-pretreated methanogenic granules. International Journal of Hydrogen Energy, 33(22): 6498-6508.

[2] Pasternak, K., Kocot, J., Horecka, A. 2010. Biochemistry of Magnesium. Journal of Elementology, 15(3): 601-616.

[3] Lutpi, N. A., Jahim, J. M., Mumtaz, T., Abdul, P. M., Nor, M. T. M. 2015. Physicochemical characteristics of attached biofilm on granular activated carbon for thermophilic biohydrogen production, RSC Advances, 5: 19382-19392.

[4] Lutpi, N. A., Jahim, J. A., Mumtaz, T., Harun, S., Abdul, P. M. 2016. Batch and continuous thermophilic hydrogen fermentation of sucrose using anaerobic sludge from palm oil mill effluent via immobilisation technique. Process Biochemistry, 51(2): 297-307. 
[5] Dubois, M., Gilles, K. A., Hamilton, J. K., Rebers, P. A., Smith, F. 1956. Colorimetric method for determination of sugars and related substances. Analytical Chemistry, 28(3): 350-356.

[6] Feng, Y., Li, G. H., Mei, H. Y., Zhang, L. S. 2013. The Effect of magnesium ions on the hydrogen-producing bacteria in the water during the ecological restoration process. Advanced Materials Research, 610613: 264-267

[7] Webb, M. 1949. The effect of magnesium on the growth of bacteria in simple. The Influence of Magnesium on Cell Division, 3: 418-424.

[8] Moreira, J., Gomes, L., Araújo, J., Miranda, J. 2013. The effect of glucose concentration and shaking conditions on Escherichia coli biofilm formation in microtiter plates. Chemical Engineering Science, 94:192-199.

[9] Zhang, G., Cao, J., Mao, Z., 2009. Influence of $\mathrm{Mg}^{2+}$ on the growth and activity of sulfate reducing bacteria. Hydrometallurgy, 95: 127-134.

[10] Ng, T. S., Desa, M. N. H., Sandai, D., Chong, P. P., Than, L. T. L. 2015. Phylogenetic and transcripts profiling of glucose sensing related genes in Candida Glabrata. Jundishapur. Journal of Microbiology, 8(11) e25177.

[11] Stewart P. S., Costerton J. W. 2001. Antibiotic resistance of bacteria in biofilms. Lancet, 358: 135-138.

[12] Hall, S., Costerton, J., Stoodley, P. 2004. Bacterial biofilms: From the natural environment to infectious diseases. Nature Reviews Microbiology, 22: 95-108. 